\title{
Factors influencing fluffy layer suspended matter (FLSM) properties in the Odra River - Pomeranian Bay - Arkona Deep System (Baltic Sea) as derived by principal components analysis (PCA), and cluster analysis (CA)
}

\author{
J. Pempkowiak ${ }^{1}$, J. Beldowski ${ }^{1}$, K. Pazdro ${ }^{1}$, A. Staniszewski ${ }^{1}$, A. Zaborska ${ }^{1}$, T. Leipe ${ }^{2}$, and K. Emeis ${ }^{3}$ \\ ${ }^{1}$ Institute of Oceanology, ul. Powstanców Warszawy 55, 81-712 Sopot, Poland \\ ${ }^{2}$ Institute of Baltic Sea Research, Seestrasse 15, 18119 Rostock-Warnemuende, Germany \\ ${ }^{3}$ Institute of Biogeochemistry and Marine Chemistry, Hamburg University, Bundesstrasse 55, 20146 Hamburg, Germany
}

Received: 20 October 2004 - Published in Hydrology and Earth System Sciences Discussions: -

Revised: 15 May 2005 - Accepted: 1 June 2005 - Published: 14 June 2005

\begin{abstract}
Factors conditioning formation and properties of suspended matter resting on the sea floor (Fluffy Layer Suspended Matter - FLSM) in the Odra river mouth - Arkona Deep system (southern Baltic Sea) were investigated.

Thirty FLSM samples were collected from four sampling stations, during nine cruises, in the period 1996-1998. Twenty six chemical properties of the fluffy material were measured (organic matter-total, humic substances, a variety of fatty acids fractions, $\mathrm{P}, \mathrm{N}, \delta 13 \mathrm{C}, \delta 15 \mathrm{~N} ; \mathrm{Li}$; heavy metals$\mathrm{Co}, \mathrm{Cd}, \mathrm{Pb}, \mathrm{Ni}, \mathrm{Zn}, \mathrm{Fe}, \mathrm{Al}, \mathrm{Mn}, \mathrm{Cu}, \mathrm{Cr})$. The so obtained data set was subjected to statistical evaluation.

Comparison of mean values of the measured properties led to conclusion that both seasonal and spatial differences of the fluffy material collected at the stations occured. Application of Principal Component Analysis, and Cluster Analysis, to the data set amended with environmental characteristics (depth, salinity, chlorophyll $a$, distance from the river mouth), led to quantification of factors conditioning the FLSM formation. The five most important factors were: contribution of the lithogenic component (responsible for 25\% of the data set variability), time dependent factors (including primary productivity, mass exchange with fine sediment fraction, atmospheric deposition, contribution of material originating from abrasion-altogether $21 \%$ ), contribution of fresh autochtonous organic matter (9\%), influence of microbial activity $(8 \%)$, seasonality $(8 \%)$.
\end{abstract}

Correspondence to: J. Pempkowiak

(pempa@iopan.gda.pl)

\section{Introduction}

Material transport in the marine environment is important as regards a number of problems, ranging from elemental biogeochemical cycles to the exposure of biota to pollutants. An important aspect in this respect is factors influencing properties of suspended matter in the coastal environment. The dispersal of chemical species in the water column is determined by a variety of processes such as coastal circulation, particle absorption and adsorption, vertical and horizontal scavenging (Duursma and Carroll, 1996). The contribution of the processes to particulate matter formation varies seasonally, since the climate modifies both hydrological factors and biological activity (Alldredge and Gotschalk, 1990; Mayer-Reil, 1994; Gustafsson et al., 1998; Lund-Hansen et al., 1999; Mayer, 1999; Leipe et al., 2000; Löffler et al., 2000; Emeis et al., 2002, Martino et al., 2002; Pempkowiak et al., 2002).

An important feature of the phenomenon is suspended matter formation and transport in the near-bottom water layer. As depicted in Fig. 1, particulate matter there is formed from suspended matter entering the coastal environment with river run-off, produced by abrasion of the shore and shallow sea bottom, primary production, atmospheric deposition, autogenic mineral formation, and direct anthropogenic discharges (Jago and Jones, 1998; Jones et al., 1998; Bianchi et al., 2002; Pempkowiak et al., 2002). En route from the high-energy, shallow, coastal environment to the low-energy, deep, depositional basins the matter is a subject to later resuspension, migration driven by near-bottom currents, and sedimentation (Emeis et al., 2002).Wind-induced currents (Lund-Hansen et al., 1997) and aggregation of suspended matter particles (Thomsen and Ritzrau, 1996) are thought to

(C) 2005 Author(s). This work is licensed under a Creative Commons License. 


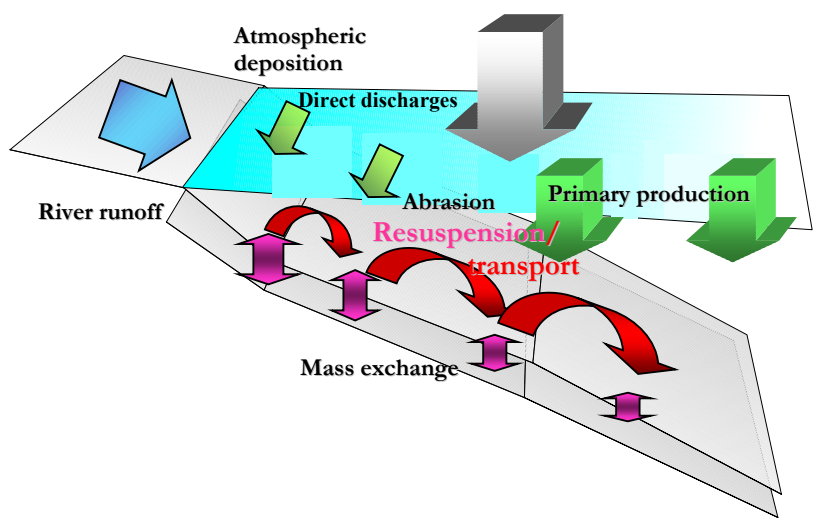

Fig. 1. A schematic indicating sources and fate of FLSM in the near shore environment.

be major factors influencing near bottom transport. However, in periods of calm weather, suspended-matter sedimentation leads to the formation of a high-density fluffy suspended matter (FLSM) layer resting on the sea bottom. Once the FLSM is at rest, both physical and biological processes contribute to the incorporation of the suspended matter into the sediments (Gerino, 1990; Wheatcroft, 1992). The same factors cause fine particles to be released from the sediment and, at least temporarily, incorporated into the suspended matter layer (Pempkowiak et al., 2002). As a consequence, components of FLSM originate from a number of sources, while a number of processes acts to integrate the components into a homogenous material eventually deposited in the low energy depositional areas.

Although individual processes contributing to the FLSM formation and properties are obvious, little is known on their relative importance in an actual coastal environment. This is, at least partly, due to high variability of the coastal environment. Thus a prolonged study, in a course of which a transect from a shallow, highly dynamic near shore environment, to a low energy, depositional basin, was probed repeatedly for FLSM, was carried out, in order to overcome the environmental variability (Emeis et al., 2002; Christiansen et al., 2002).

In this paper we report results of this study carried out in the Odra River - Pomeranian Bay - Arkona Deep System (southern Baltic). Samples of FLSM were collected in the course of a two years long program conducted in the frame of the Baltic Sea System Study (Emeis et al., 2002; Christiansen et al., 2002). Composition and properties of the samples were then measured, and have been a subject of several publications (Emeis et al., 2002; Pempkowiak et al., 2002; Pazdro et al., 2001; Witt et al., 2001; Löffler et al., 2000; Leipe et al., 2000). However, due to the diversified nature of the collected material, no factors responsible for the matter properties were evident and have been named yet. Therefore statistical evaluation, by means of multivariate statistical

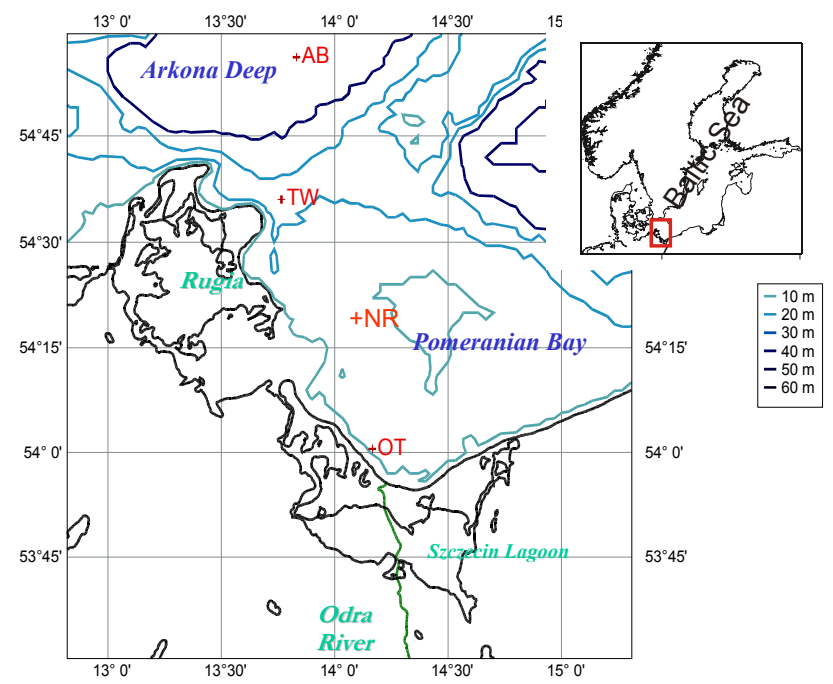

Fig. 2. Distribution of sampling stations in the study area (OT Odas Tonne, NR - Norperd Rinne, TW - Tromper Wiek, AB Arkona Becken).

Table 1. Geographical positions, water depths, and average nearbottom water properties at the sampling stations.

\begin{tabular}{cccccc}
\hline Station & $\begin{array}{c}\text { Latitude } \\
(\mathrm{N})\end{array}$ & $\begin{array}{c}\text { Longitude } \\
(\mathrm{E})\end{array}$ & $\begin{array}{c}\text { Water depth } \\
(\mathrm{m})\end{array}$ & $\begin{array}{c}\text { Oxygen } \\
\left(\mathrm{ml} \times 1^{-1}\right)\end{array}$ & $\begin{array}{c}\text { Salinity } \\
(\mathrm{PSU})\end{array}$ \\
\hline OT & $54^{\circ} 05^{\prime}$ & $14^{\circ} 10^{\prime}$ & 16 & 5.8 & 7.5 \\
$\mathrm{NR}$ & $54^{\circ} 22^{\prime}$ & $13^{\circ} 52^{\prime}$ & 20 & 6.9 & 7.7 \\
$\mathrm{TW}$ & $54^{\circ} 36^{\prime}$ & $13^{\circ} 46^{\prime}$ & 26 & 5.9 & 9.1 \\
$\mathrm{AB}$ & $54^{\circ} 56^{\prime}$ & $13^{\circ} 50^{\prime}$ & 47 & 2.6 & 16.4 \\
\hline
\end{tabular}

methods, has been carried out in order to find and quantify the most important factors conditioning the FLSM formation. Both cluster and principal components analyses were used. The results, presented in this publication, point out at, and quantify the contribution of lithogenic material, fine sediment fraction, and freshly produced organic matter; all modified by bacterial activity, as factors actually responsible for FLSM properties.

\section{The study area}

The Pomeranian Bay - Arkona Deep system extends from the Odra River estuary to the Arkona Basin (Fig. 2). Four sampling stations - Odas Tonne (OT), Nordperd Rinne (NR), Tromper Wiek (TW), and Arkona Becken (AB) were established there, along a transect with the water depth increasing from $16 \mathrm{~m}$ at OT to $47 \mathrm{~m}$ at $\mathrm{AB}$. The geographical co-ordinates and characteristics of the sampling stations are given in Table 1. 
Table 2. Expeditions, station coverage, and the collected samples numbers.

\begin{tabular}{clcccc}
\hline Expedition & Period & $\begin{array}{c}\text { Odas Tonne } \\
(\mathrm{OT})\end{array}$ & $\begin{array}{c}\text { Norperd Rinne } \\
(\mathrm{NR})\end{array}$ & $\begin{array}{c}\text { Tromper Wiek } \\
(\mathrm{TW})\end{array}$ & $\begin{array}{c}\text { Arkona Becken } \\
(\mathrm{AB})\end{array}$ \\
\hline 1 & 1-11 October 1996 & P21,P22 & P14,P15 & P6,P7 & P1 \\
2 & 14-19 March 1997 & P23 & P6 & P8 & P2 \\
3 & 10-15 June 1997 & P24 & & P9 & P3 \\
4 & 18-22 August 1997 & P25 & & & P4 \\
5 & 12-17 October 1997 & P26 & P17 & P10 & \\
6 & 1-9 December 1997 & P27 & P18 & P11 & \\
7 & 16-22 March 1998 & P28 & & & \\
8 & 22-27 June 1998 & P29 & P19 & P12 & P5 \\
\hline
\end{tabular}

The hydrography of this area is influenced by the Odra with its annual water run-off of about $17 \mathrm{~km}^{3}$, and by the weather conditions, which influence the water circulation. Sediments in the Pomeranian Bay are temporarily covered by a thin fluffy layer of suspended matter (FLSM). On a weight basis the quantity of FLSM is estimated to range from 2 to $4 \mathrm{mg} / \mathrm{cm}^{3}$. The layer is 1 to $3 \mathrm{~cm}$ thick. The sediments are composed of a well sorted fine sand $(0.1$ to $0.25 \mathrm{~mm})$ grading to muddy sand below $20 \mathrm{~m}$ water depth and to mud in the depositional basin of the Arkona Deep.

The winds are the main factor governing the currents in the Pomeranian Bay (Löffler et al., 2000). Density-driven currents and tides are of minor importance. Easterly winds dominate between February and May. At this time surface water moves to the north while the near-bottom water layer is transported to the east. Westerly winds are dominant between June and September, while westerly to south-westerly winds generally occur between October and January. During these periods the surface water is transported eastwards along the coast. This surface current is compensated by a nearbottom current, that flows towards the Arkona Deep along the Island of Rugen (Siegel et al., 1999). The sampling stations are situated along a transect following the main transport route of the near-bottom water layer and the suspended matter it carries (Leipe et al., 2000). Although the grain size at the sediment surface was different at the sampling stations (Lund-Hansen et al., 1999), the critical shear stress at all stations was surprisingly uniform, corresponding to flow velocities of about $4 \mathrm{~cm} \mathrm{~s}^{-1}$. This low value is due to the presence of an organic-rich layer resting on top of the actual sediment surface - FLSM. A flow velocity of $4.5 \mathrm{~cm} \mathrm{~s}^{-1}$ is required to transport the FLSM (Leipe et al., 2000; Christiansen et al., 2002). The Arkona Deep acts as a final deposition area for the material, with an average mass accumulation rate from 1.0 to $1.8 \mathrm{~kg}$ (dry mass) $\mathrm{m}^{-2}$ year $^{-1}$ (Widrowski and Pempkowiak, 1986; Pempkowiak, 1991; Emeis et al., 2002).

In the period from October 1996 to December 1998 nine expeditions were carried out to the study area. Station coverage is given in Table 2.

\section{Sources and composition of FLSM in the study area}

Altogether, the Odra discharges about 425000 t (dry matter)/year of suspended solids. The material is rich in organic matter (15.3\% particulate organic carbon) and heavy metals $\left(\mathrm{Pb}-200 \mu \mathrm{gg}^{-1}, \mathrm{Zn}-1700 \mu \mathrm{gg}^{-1}, \mathrm{Cu}-120 \mu \mathrm{g} \mathrm{g}^{-1}, \mathrm{Cd}\right.$ $-9 \mu \mathrm{gg}^{-1}, \mathrm{Hg}-2.5 \mu \mathrm{gg}^{-1}$ ) (Emeis et al., 2002). In comparison to pelagic suspended matter (PSM), FLSM is rich in hydrated three-layer and mixed-layer silicates such as illite and smectite (Leipe et al., 2000). This is due to their ability to enhance aggregation and sedimentation of suspended matter particles (Leipe et al., 2000). The organic matter content in FLSM is much smaller than in the nepheloid layer suspended matter (NLSM), indicating that organic matter may be undergoing mineralisation in the course of sedimentation. Another possibility is the exchange of particles with surface sediments (Pempkowiak et al., 2002). This conclusion is supported by the fact that the organic matter content at the deepest station $(\mathrm{AB}-47 \mathrm{~m})$ is smaller than at the most shallow one (OT $-16 \mathrm{~m})$. Fe-oxihydroxides are present in FLSM: the content of these oxides decreases from about $10 \%$ at OT to $5 \%$ at TW and $3 \%$ at AB. Mn-oxihydroxides are present only at OT (2\%) (Leipe et al., 2000). This is most likely due to the anoxic conditions in the uppermost sediments of deeper stations, causing reduction of $\mathrm{Fe}(\mathrm{III})$ to $\mathrm{Fe}(\mathrm{II})$ and of $\mathrm{Mn}$ (IV) to $\mathrm{Mn}(\mathrm{II})$. The reduced species migrate to the overlying water, where they are oxidised and precipitated (Pempkowiak et al., 2000).

\section{Experimental}

The fluffy layer covering the sediment surface was collected by scuba divers, or by a remotely operated vehicle (ROV). The material (FLSM) was siphoned from the sediment surface by an on-board pump and transferred into 1001 containers.

The particulate matter was separated from the water by filtration through pre-weighed glass-fibre filters and freeze dried before further analyses. A set of 26 properties of 


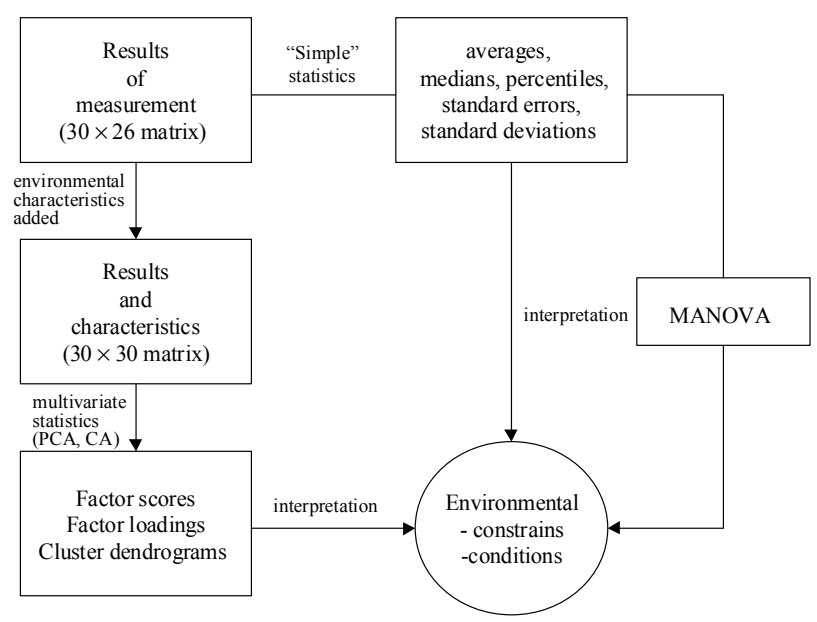

Fig. 3. A schematic of the approach to the statistical evaluation of the data set.

the so obtained material were analysed (total organic nitrogen - N_TOT, total phosphorous - P_PPM, total carbon $\mathrm{TC}$, loss on ignition - LOI, total organic carbon - C_ORG, total inorganic carbon $-\mathrm{CaCO}_{3}, \mathrm{C}^{13} / \mathrm{C}^{12}$ isotopes ratio $\delta^{13} \mathrm{C}, \mathrm{N}^{14} / \mathrm{N}^{15}$ isotopes ratio $-\delta^{15} \mathrm{~N}$, total free fatty acids - TFAF, the sum of saturated acids - SATURATE, the sum of branched fatty acids - BRANCHED, the sum of monounsaturated fatty acids MONOUNSA, the sum of polyunsaturated fatty acids - POLYUNSA, humic substances - HS, humic acids - HA, fulvic acids - FA, total metals: $\mathrm{Zn}, \mathrm{Ni}, \mathrm{Cu}$, $\mathrm{Pb}, \mathrm{Al}, \mathrm{Mn}, \mathrm{Fe}, \mathrm{Co}, \mathrm{Li}, \mathrm{Cd}, \mathrm{Cr}$ ). The following procedures were used. Total organic carbon $\left(\mathrm{POC}, \delta^{13} \mathrm{C}\right)$ and total organic nitrogen (N_TOT, $\delta^{15} \mathrm{~N}$ ) were measured in a Fission Instruments $\mathrm{H} \delta 8 \mathrm{CHN}$ Analyser, connected to an isotope ratio mass-spectrometer (Finnigan MAT Delta $\mathrm{S}$ ). Pure $\mathrm{N}_{2}$ and $\mathrm{CO}_{2}$ were used as reference gases. Air nitrogen and NBS-18 reference carbonate were used for standarisation.

Heavy metals $(\mathrm{Cd}, \mathrm{Pb}, \mathrm{Zn}, \mathrm{Cu}, \mathrm{Ni}, \mathrm{Co}, \mathrm{Cr}, \mathrm{Fe}, \mathrm{Mn}, \mathrm{Al})$ were analysed in a model Video 11E atomic absorption spectrometer after $500 \mathrm{mg}$ (dry weight) subsample was wet digested (HF: $\mathrm{HNO}_{3}: \mathrm{HClO}_{4}=2: 2: 1$ ), excess acids were evaporated, and the dry residue dissolved in $10 \mathrm{~cm}^{3} 0.1 \mathrm{~mol} / \mathrm{dm}^{3}$ $\mathrm{HNO}_{3}$. Electrothermal (Co, Cd) and flame (other metals) atomizations were applied. Quality assurance of the analyses was assessed by incorporating into the analysis an ICES/SCOR certified, Baltic Sea bottom sediment sample, and ICES marine sediment sample. Accuracy as characterized by recovery was in the range from $83 \%(\mathrm{Fe})$ to $108 \%$ $(\mathrm{Cd})$, while precision, given by relative standard deviation, was in the range from $5 \%(\mathrm{Fe})$ to $13 \%(\mathrm{~Pb})$.

The samples were analysed for total carbon (TC) by dry combustion and for total inorganic carbon $\left(\mathrm{CaCO}_{3}\right)$ by $50 \%$ phosphoric acid treatment. An IR detector (Eltra Metotyl CS $1000 \mathrm{~S} \mathrm{C} / \mathrm{S}$ analyser) was used to determine evolving $\mathrm{CO}_{2}$.
Concentration of $\mathrm{Li}$ and $\mathrm{P}$ were analysed by means of automated electron probe $\mathrm{x}$-ray micro analysis (EPXHA; Leipe et al., 2000).

For fatty acids analyses, a 1-2 g subsample of the freezedried material was extracted three times with 2:1 chloroform methanol mixture. The fatty acids contained in the combined extracts are referred to as free fatty acids (TFAF). The solid residue was then saponified with $0.5 \mathrm{~mol} / \mathrm{dm}^{3} \mathrm{KOH}$ in a 95:5 v/v methanol:water solution and filtered. The acids determined in the resulting filtrate are referred to as bound fatty acids. After separation from other lipid components the fatty acids were derivatized into coumaryl esters and analysed quantitatively using high performance liquid chromatography in a reversed phase column, a gradient methanol:water mobile phase and a fluorescence detector were used. Details of the procedure were described earlier (Pazdro and Falkowski, 1994). Individual fatty acids were quantified using calibration curves based on actual standards (Sigma), and the above described derivatization procedure. The precision of the results, expressed as a relative standard deviation, varied from 1.4 to $20 \%$ for individual compounds and from 0.4 to $16 \%$ for the total fatty acid content. Concentrations of fatty acids within the following groups were then added and are referred to as total saturated fatty acids - SATURATE (straight chain saturated fatty acids with carbon atoms in the range from 8 to 24 (C8:0 to $\mathrm{C} 24: 0)$, total monounsaturated fatty acids (C14:1 to C22:1) - MONOUNSA, total polyunsaturated fatty acids (C18:2 to C22:6) - POLYUNSA, and branched fatty acids $\left(\mathrm{C}_{\mathrm{ai}, \mathrm{i}} 15: 0\right.$ and $\left.\mathrm{C}_{\mathrm{a} i \mathrm{i}} 17: 0\right)$ - BRANCHED.

Humic substances were extracted repeatedly (five fold) from $2 \mathrm{~g}$ of the freeze-dried material by means of a standard alkaline $\left(0.1 \mathrm{~mol} / \mathrm{dm}^{3} \mathrm{NaOH}\right)$ extraction. The combined extract was acidified to $\mathrm{pH} 2.0$ with $3 \mathrm{~mol} / \mathrm{dm}^{3} \mathrm{HCl}$. Precipitated humic acids (HA) were separated (centrifugation), purified and freeze-dried, while dissolved fulvic acids (FA) were sorbed on Amberlite XAD-2 resin, extracted with $0.1 \mathrm{~mol} / \mathrm{dm}^{3} \mathrm{NH}_{4} \mathrm{OH}$, freeze dried and weighted. Details of the procedure are described elsewhere (Pempkowiak, 1989).

\section{Statistics}

Two approaches have been taken in order to evaluate statistically and characterize the data set originating from the measurements. The strategy employed is depicted in Fig. 3. Results of the measurements ( 30 samples $\times 26$ properties measured) were a subject to simple statistics. The obtained values were then used to assess spatial and temporal changes of FLSM properties. The average values were also subjected to the MANOVA in order to assess the significance of differences.

The multivariate statistics were applied as another approach. The principal aim of multivariate analysis is to explain variation in a multivariate data set by as few "factors" as 
possible, and to detect "hidden" multivariate data structures. This is carried out by developing a set of new "dimensions" - factors, which explain variations in the data matrix (principal components -PCs, in the case of Principal Components Analysis- PCA).

Principal component analysis (PCA), also known as empirical orthogonal function analysis, is an often adopted approach in geochemistry related studies since the pioneering work in this field by Wiwant et al. (1975). PCA objectively extracts the optimal linear lower-dimensional structure from a multivariate dataset. Feature extraction, or pattern recognition, is probably the most appealing of the many purposes for which PCA can be used. The attempt is then made to associate PCA modes with actual physical modes in the dataset. Whereas such an attempt is usually successful in case of few first modes (that is, these that explain most variance in the total dataset), the spatial orthogonality of PCA modes often causes higher-numbered modes to bear predictable geometric relationships to the first mode rather than to represent independent physical modes (Meglen, 1992; Ruessink et al., 2004).

PCA is commonly applied to geochemical data sets which consist of columns - representing sample properties and rows representing individual samples. As result of PCA analysis a set of PCs is calculated equal in number to the number of properties (columns). The analysis is successful if just few PCs explain large proportion of the data set variation. Successful PCA implies also that significance (meaning) of the factors is found. This might, and often do, cause problems. Typically correlation between factors and properties (PCs loadings), and numerical values of factors for samples (PCs scores) are used to explain actual meaning of PCs. After analysis, rotation is applied in order to optimize factor loadings (De Lazzari et al., 2004; Liu et al., 2003; Reiman et al., 2002; Smoleñski et al., 2002; Persson and Wedborg, 2001; Podani, 2000; Brown, 1998; Shine et al., 1995; Szefer et al., 1995; Meglen, 1992, to name just a few).

Before applying PCA, the data set ( 26 properties by 30 samples) was ammended with environmental characteristics of the sampling stations and seasons (distance from the Odra river mouth, water depth, water temperature, water chl $a$ concentration at the sampling stations). The so obtained data table comprised 30 rows (cases or samples) and 30 columns (26 properties measured +4 "properties" characterizing hydrography of sampling stations and seasonality of expeditions). Then the $30 \times 30$ data matrix was subjected to analyses of both clusters (CA) and principal components (PCA).

To probe agglomeration of data, cluster analysis was used. City block distances and squared ordering were used throughout the CA of the data matrix. The dimensionality of the data matrix was reduced and meaning assessed using principal components scores (PCS), and principal components loadings (PCL). Only PCL with eigenvalues exceeding 1 were analysed. Varimax rotation was used in PCA in this study.

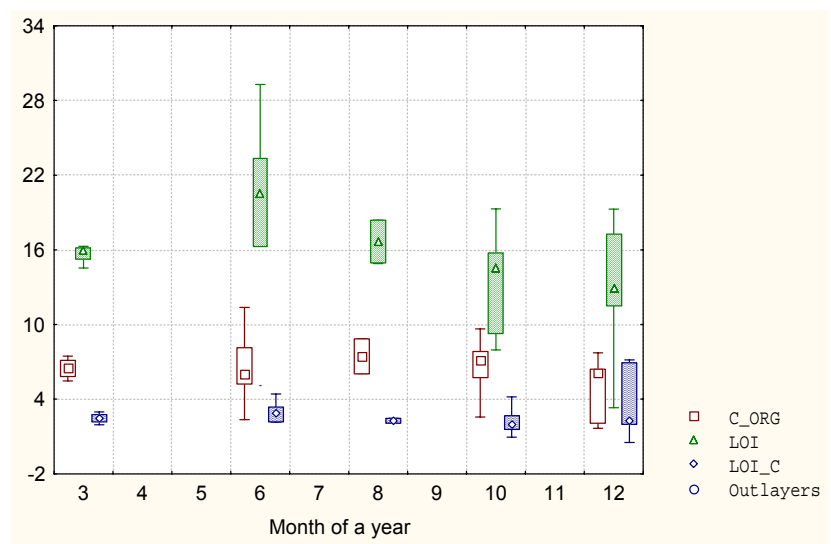

Fig. 4. Seasonal changes of organic carbon (C_ORG), loss on ignition (LOI) and ratio of LOI to C_ORG (LOI_C); C_ORG and LOI in \%, LOI_C - dimensionless.

Before applying PCA the data matrix was standarized using the standard deviation approach. This is based on replacing actual values $\left(x_{i}\right)$ with standarized ones $\left(x_{i s}\right)$. Standarization is meant to eliminate the influence of both different units, and different range of the investigated properties.

$x_{i s}=\frac{x_{i j}-\bar{x}_{i}}{s_{i}}$

where $s_{i}=\sqrt{\frac{\sum\left(x_{i j}-\bar{x}_{i}\right)}{n-1}} ; n-$ number of samples analysed.

Standarization by maximum values was carried out throughout CA.

$x_{i s^{\prime}}=x_{i j} / \max _{j}\left\{x_{i j}\right\}$

In this approach the value of 1 is assigned to the maximum value of a given property while the range of the standarized values is $<0,1>$.

The statistical software package Statistica 6.0 for Windows was utilized.

\section{Results and discussion}

\subsection{Spatial and temporal distribution pattern}

To characterize concentrations and properties of organic matter in the samples the following properties of FLSM were used: loss on ignition (LOI), organic carbon (C_ORG), concentrations of humic acids (HA), fulvic acids (FA), and humic substances $(\mathrm{HS}=\mathrm{HA}+\mathrm{FA})$, total nitrogen $(\mathrm{N})$, total phosphorus $(\mathrm{P})$, a number of fatty acids fractions (saturated, monounsaturated, polyunsaturated, branched). Besides actual concentrations, values standarized to LOI or/and C_ORG were used when appropriate.

In Fig. 4 seasonal changes of C_ORG, LOI and LOI/C are presented. Organic carbon concentration in FLSM decreases 


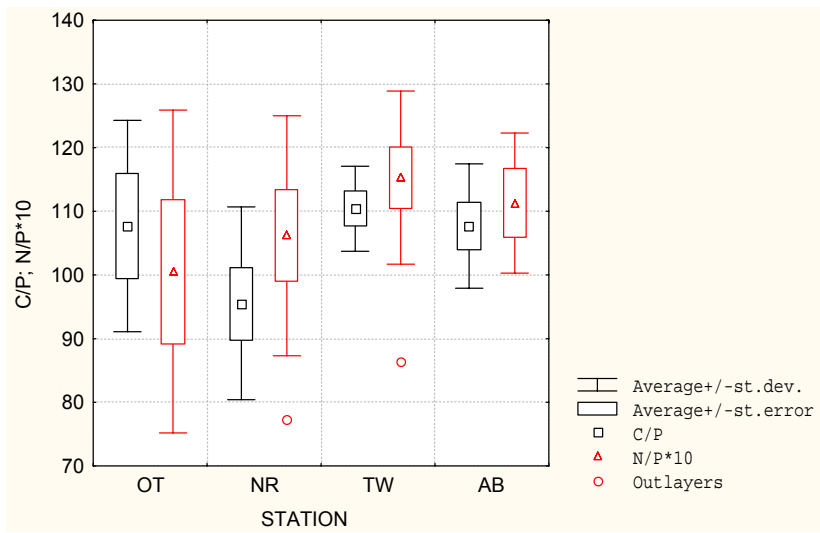

Fig. 5. Spatial distributions of $\mathrm{C} / \mathrm{P}$ and $\mathrm{C} / \mathrm{N}$ molar ratios in FLSM.

from $8 \%$ in summer to $6 \%$ in winter. However, organic carbon contribution to organic matter decreases from some $60 \%$ in summer, to $35 \%$ in winter. This unexpected feature of fluffy material might be attributed to rapid mineralization of labile organic matter produced in the course of the spring primary production in elevated summer temperatures, while organic matter produced in autumn, after sedimentation, is preserved in the near bottom layer. However, high organic matter concentrations in winter may also suggest participation of other processes, for example contributions of land derived organic matter $(15 \%$ organic carbon in the Odra river suspended matter was reported), and sedimentary organic matter (Bale and Morris, 1998).

Molar ratios of biogenic elements $(\mathrm{C}, \mathrm{N}, \mathrm{P})$ in FLSM are smaller than the Redfield ratios (Laima et al., 1999). Smaller ratios of both $\mathrm{C} / \mathrm{P}$ and N/P in winter, indicate preferential mineralization of organic nitrogen and phosphorus over organic carbon. Combined with the temporal dynamic of the C/LOI ratios, the feature suggests relatively high biochemical stability of organic compounds abundant with carbon, while nitrogen and phosphorous abundant organic compounds are easily biodegradated. The spatial distributions of $\mathrm{C} / \mathrm{P}$ and N/P, presented in Fig. 5, indicate smaller ratios in the samples collected at the nearshore station (OT and NR). This could be, most likely, attributed to the contribution of land derived organic matter. Bordovsky (1965) indicated that marine autochtonous organic matter is characterized by $\mathrm{C} / \mathrm{N}$ ratios smaller than 10, while allochtonous organic matter-with values larger than 10 . The conclusion is supported by distribution of $\delta^{13} \mathrm{C}$ and $\delta^{15} \mathrm{~N}$ in the samples, and results of earlier studies on stable isotopes ratios in the area, reported by Voss and Stock (1997). Distributions of $\delta^{13} \mathrm{C}$ and $\delta^{15} \mathrm{~N}$ clearly indicate contribution of land derived organic matter exceeding $90 \%$ at the OT station, in comparison with just above 5\% contribution in the $\mathrm{AB}$ station, although distribution of lignin oxidation products suggests less steep gradient (Miltner and Emeis, 2001). Organic matter discharged to the sea with river run-off is usually depleted with carbon and nitrogen isotopes

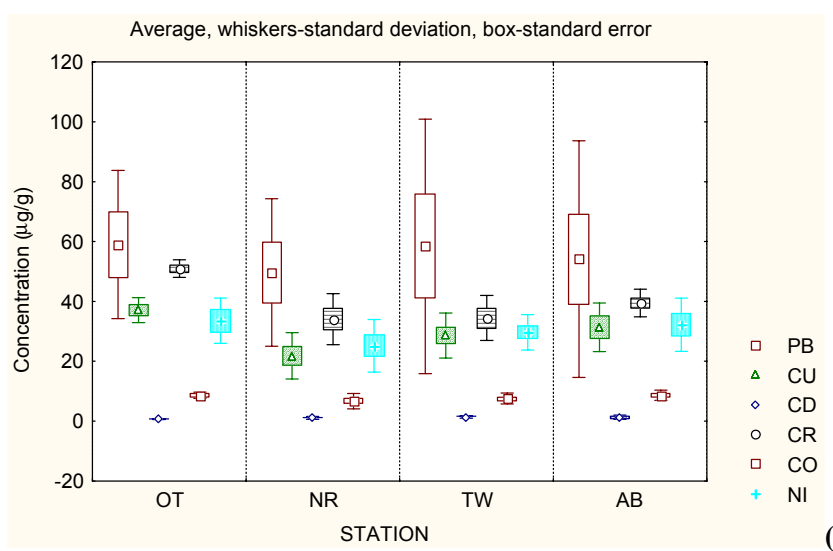

(a)

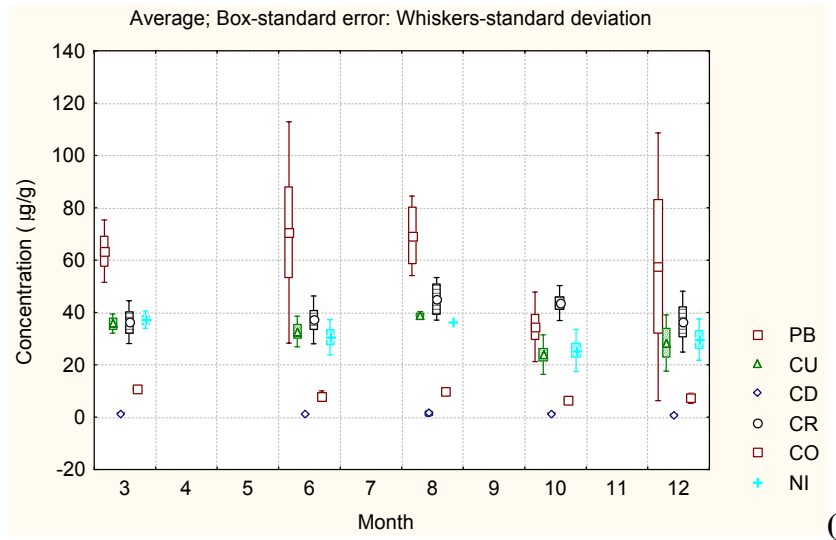

(b)

Fig. 6. Variations of heavy metals concentrations (mg/g dry matter) in FLSM (a) spatial, and (b) seasonal.

of larger molecular weight (Voss and Stock, 1997), and with nitrogen (Bordovsky, 1965). Moreover, results of this study show larger proportions of humic substances (humic acids + fulvic acids) in the fluffy material from the nearshore stations. This may be interpreted as resulting from contribution of relatively old, biochemically resistant organic matter derived from land.

On the other hand larger concentrations of labile fractions of organic matter (monounsaturated and polyunsaturated fatty acids) in the summer months, indicate contribution of relatively fresh organic matter (Wakeham et al., 1997; Pazdro et al., 2001). The larger concentrations of saturated fatty acids in winter months result from relative stability of saturated as compared to the unsaturated acids (Sun et al., 1997; Laima et al., 1999). This feature is consistent with discussed reasons for dynamic behaviour of the organic FLSM component, and its elemental composition.

Diagrams showing heavy metals distribution are presented in Fig. 6. Substantial spatial (Fig. 6a) and temporal (Fig. 6b) variations of heavy metals were found in the collected samples of FLSM. This, most likely, reflects diversified origin of fluffy material (river run-off, abrasion of shores and sea 
bottom, biogenic input, and red-ox phenomena at the sediment/water interface). After normalizing concentrations to aluminium a pattern governed by both, seasonality and distance from the Odra river mouth, emerges. FLSM is enriched with biogenic metals $(\mathrm{Co}, \mathrm{Cd}, \mathrm{Cu})$ in summer, while concentrations of these metals in winter are much smaller (Fig. 7a). This was already reported for cadmium in FLSM of the area by Staniszewski et al. (2001). The differences evaluated using the MANOVA proved statistically significant. The explanation that algae (primary production) contribute biogenic heavy metals to FLSM is also substantiated by depletion of dissolved cadmium in pelagic suspended matter, during summer (Pempkowiak et al., 2002), and enrichment of suspended cadmium in the Pomeranian Bay during algal blooms (Pohl et al., 1998). Some metals do not show clear seasonal pattern, although they are regarded as biogenic. This concerns elements characterized by large concentrations in FLSM, hardly affected by incorporation of heavy metals to FLSM in the course of primary productivity. Unusual behaviour of Mn might be attributed to the red-ox phenomena (Heiser et al., 2001; Dehairs et al., 1989). Leipe et al. (2000) indicated that FLSM in the Pomeranian Bay is enriched with hydrated three-layer and mixed-layer silicates such as illite, illite/mixed layers, and smectite. These minerals posses a strong affinity to organic matter, and are readily colonized by microorganisms (Mayer, 1999). This supports conclusion on strong influence of temperature dependent biological processes on concentrations of selected heavy metals in FLSM. No easily recognizable pattern has been found for lead and chromium. Both the metals, attributed to the "scavenged" group, show high concentrations dynamics, reflecting general patchiness, caused by periodical supply of suspended material from the Szczecin Lagoon in this highly dynamic, near shore area of the Pomeranian Bay (Emeis et al., 2002), and both natural and anthropogenic sources of lead (Hinrichs et al., 2002).

A common feature of all metals distributions is a general tendency for decreasing concentrations in the offshore direction (Fig. 7b). This feature is caused by high concentrations of heavy metals in suspended matter supplied to the Pomeranian Bay with the Odra run-off. For example concentration of Cd in the Szczecin Lagoon suspended matter is as high as $5 \mu \mathrm{g} / \mathrm{g}$ (Leipe et al., 2000). On entering the marine environment the heavy metals abundant, land derived, material is "diluted" with material originating from coastal erosion. Similar distributions are observed in other estuaries (Belzunce et al., 2001; Borg and Jonsson, 1996). Relatively large concentrations of heavy metals are observed in material collected from the Arkona Deep acting as a depositional ground for suspended matter in the region. The increased concentration of heavy metals there indicates that the deep acts as depositional basin for material originating not only from the Pomeranian Bay but also from other sources, in the large catchment area of the basin (Löffler et al., 2000). However, most organic matter comprised in FLSM is au-

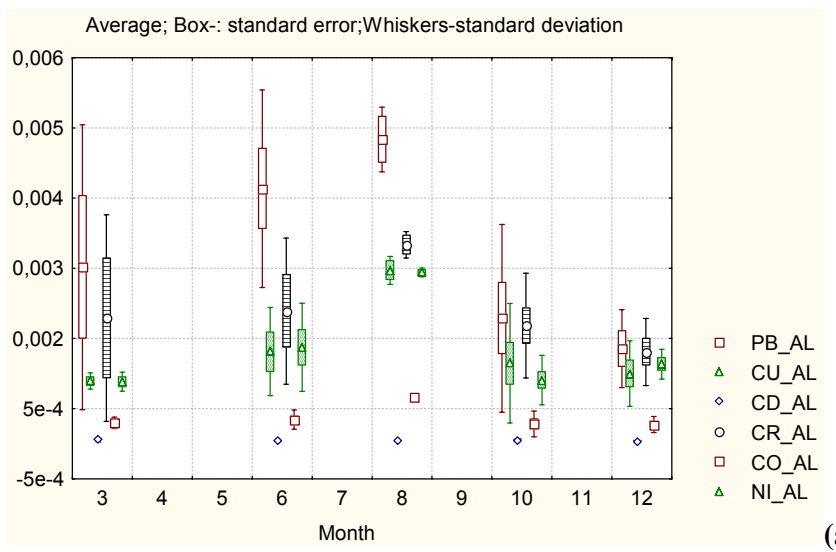

(a)

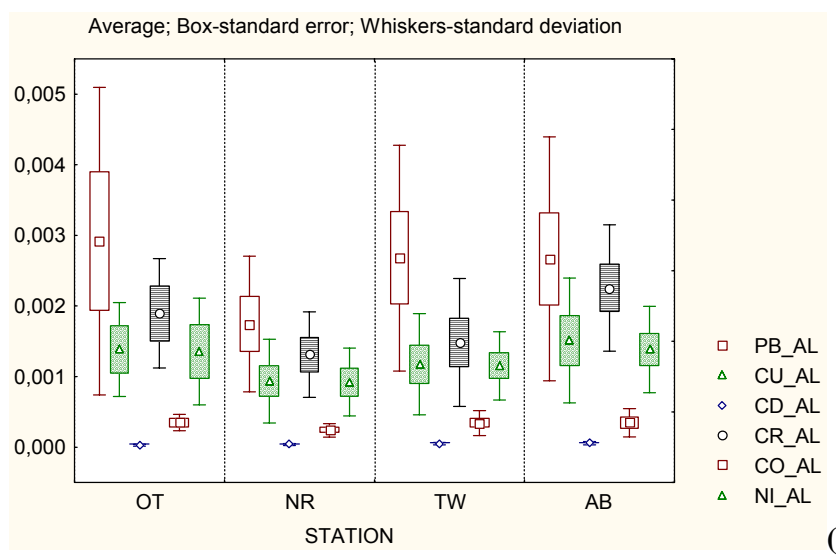

(b)

Fig. 7. Changes in heavy metals concentrations in FLSM normalized to Al (a) seasonal, and (b) spatial.

tochthonous, as indicated by stable carbon $\left(\delta^{13} \mathrm{C}\right)$ and nitrogen $\left(\delta^{15} \mathrm{~N}\right)$ isotopes ratios. This feature was thoroughly discussed and explained by Voss and Stock (1997).

Apart from $\delta^{13} \mathrm{C}$ and $\delta^{15} \mathrm{~N}$ values which clearly differentiate FLSM collected at different stations, chemical properties of FLSM are scattered. Although average values discussed above indicate spatial and temporal pattern, large standard errors underline intensive scatter of results. Properties of FLSM collected at subsequent stations within one expedition, frequently show no pattern at all, or pattern different from that emerging from profiles of average properties. This may originate, as indicated earlier, from diversified sources of suspended matter, supplying the system with suspended matter with varying intensity. Moreover, the shallow, nearshore environment is highly dynamic since wind induced currents cause displacement of FLSM with frequency depending on the water depth. It is estimated that at the OT station events of FLSM resuspension and transport occur twenty to forty times per year, while at the TW station such events occur few times per year at the most. It may also happen that, at least temporarily, direction of FLSM offshore transport is reversed. 


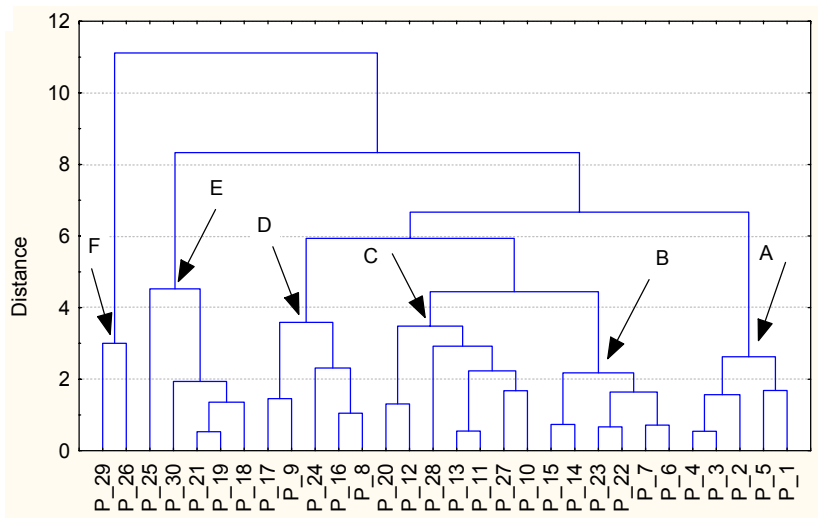

Fig. 8. Dendrogram of the analysed cases (P1-P5: samples collected at AB, P6-P13: samples collected at NR; P14-P20: samples collected at TW; P21-P30 samples collected at OT).

A suitable tool for investigating hidden patterns in data sets of the described sort is multivariate statistical analysis. From among many statistical techniques, principal component analyses (PCA), and cluster analyses (CA) are frequently applied to geochemical and chemical data sets (Manly, 1990; Meglen, 1992; Szefer et al., 1995), and are used in this study to assess factors conditioning FLSM. Meglen (1992) suggests that multivariate analysis begins with the CA, and then is followed and confirmed by a multistage PCA.

\subsection{Cluster analysis (CA)}

A dendrogram showing distribution and association of the analysed samples is presented in Fig. 8. Six major clusters, marked with letters, can be recognized in the dendrogram. Cluster A represents samples collected at the AB station. The samples are clearly separated from other samples collected in the system. This underlines substantial difference between properties of the $\mathrm{AB}$ samples and those collected from other stations, closer to the Odra mouth. Both anoxic conditions and prolonged time of the matter residence on the sea floor may be responsible for the phenomenon (Siegel et al., 1999). Moreover, Pempkowiak et al. (2002) indicated substantial mass exchange between FLSM and fine fraction of surface sediments. Substantial contribution of suspended matter from other areas than Pomeranian Bay/Odra River system to FLSM was reported (Emeis et al., 2002), and may contribute to the specific properties leading to the separation of the AB station samples, from others collected in the system. Cluster F, opposite to cluster A is composed of two samples collected at the OT station, the one closest to the Odra River mouth. Both samples were collected following the period of heavy flood in the Odra catchment area and, quite likely, represent allochtonous suspended matter. Cluster B comprises samples collected at stations OT $(22,23)$, NR $(6,7)$, and TW $(14,15)$ in October 1996. Close associ-

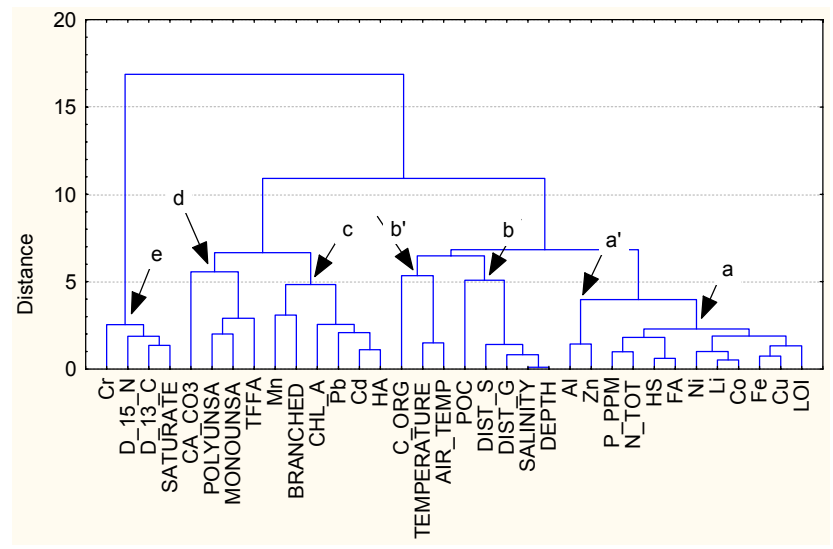

Fig. 9. Dendrogram of the analysed FLSM properties.

ation of samples indicates relative homogenity of FLSM in the Pomeranian Bay at that sampling time. However, sample 5 collected at the $\mathrm{AB}$ station at the same expedition in October 1996 is incorporated in the AB cluster (A), indicating and confirming specific composition of FLSM there.

The other three clusters $(\mathrm{C}, \mathrm{D}, \mathrm{E})$ comprise samples collected at the OT, NR, and TW stations. It is worth noticing that individual clusters comprise samples differing not only with locations where they were collected, but season as well. It is characteristic that samples from the NR station were collected several months after those from the OT station, while samples from the TW station - still later than those from the NR station (see Table 2 for comparison). This indicates that FLSM retains its properties (a memory effect) when transported from the Odra River mouth (OT station) seaward (NR station, followed by TW station) to a degree enabling time independent clustering. The distribution can be used for assessing time and velocity of migration. In 4 out of 5 instances when the "movement" of samples characterized by similar properties was noticed, the time required for FLSM to move from OT to TW stations is in the range from 4-9 months. The thesis that pattern of FLSM properties can be recognized after several months and after covering some $200 \mathrm{~km}$ was also investigated using method developed by Krumgaltz (1993). The method is based on measuring ratios of heavy metals concentrations (Table 3) and using the values for fingerprinting the samples. Specific values of the ratios can be detected along the transect, corresponding to patterns found in the clusters C, D, and E (Fig. 8).

In Fig. 9, a dendrogram showing distribution and association of the analysed properties is presented. Cluster $a$ comprises concentrations of lithogenic elements ( $\mathrm{Li}, \mathrm{Co}, \mathrm{Ni}, \mathrm{Fe}$ ) and properties closely associated with concentration of organic matter (LOI, FA, HS, N, P). Copper characterized by high anthropogenic enrichment factor in the Baltic sediments (Pempkowiak, 1991; Szefer et al., 1995) is also included in the cluster. This might be caused by affinity of the element to organic matter in general, and sedimentary humic 
Table 3. Fingerprinting FLSM.

\begin{tabular}{lcccccccc}
\hline \multirow{2}{*}{ Cruise date } & \multicolumn{8}{c}{ FLSM characteristics } \\
\cline { 2 - 9 } & \multicolumn{2}{c}{$\mathrm{OT}$} & \multicolumn{2}{c}{$\mathrm{NR}$} & \multicolumn{2}{c}{$\mathrm{TW}$} & \multicolumn{2}{c}{$\mathrm{AB}$} \\
& $\mathrm{Cu} / \mathrm{Co}$ & $\mathrm{Fe} / \mathrm{Co}$ & $\mathrm{Cu} / \mathrm{Co}$ & $\mathrm{Fe} / \mathrm{Co}$ & $\mathrm{Cu} / \mathrm{Co}$ & $\mathrm{Fe} / \mathrm{Co}$ & $\mathrm{Cu} / \mathrm{Co}$ & $\mathrm{Fe} / \mathrm{Co}$ \\
\hline October 1996 & $2.7^{*}$ & $0.20^{*}$ & 3.8 & 0.31 & 3.9 & 0.30 & 3.8 & 0.35 \\
March 1997 & 4.0 & 0.25 & 3.3 & 0.29 & 2.6 & 0.20 & $2.6^{*}$ & $0.20^{*}$ \\
August 1997 & 3.2 & 0.44 & 3.9 & 0.41 & 3.7 & 0.31 & 3.4 & 0.36 \\
December 1997 & 5.2 & 0.38 & $3.5^{* *}$ & $0.54^{* *}$ & 4.1 & 0.34 & 3.9 & 0.27 \\
June 1998 & 4.4 & 0.39 & 4.2 & 0.36 & $3.3^{* *}$ & $0.51^{* *}$ & 3.6 & 0.40 \\
December 1998 & 4.0 & 0.30 & 4.4 & 0.45 & 3.6 & 0.30 & $3.3^{* *}$ & $0.53^{* *}$ \\
\hline
\end{tabular}

*, ** Specific ratios of metals in samples collected along the Odra mouth - Arkona Deep transect.

substances in particular (Pempkowiak and Szponar, 1995). The lithogenic elements - organic matter cluster $(a)$ is associated with cluster $a^{\prime}$ comprising $\mathrm{Al}$ - another lithogenic element, and $\mathrm{Zn}$ - most often included in the group of "anthropogenic" metals (Szefer et al., 1995). Both the $a$ and $a^{\prime}$ clusters are closely associated with a cluster comprising salinity (SALINITY), depth of water at the sampling sites (DEPTH), and their distance from the Odra mouth (DIST). These associations point at the Odra River as the source of material, and the major factor influencing distribution of lithogenic metals in the coastal environment. Cluster $c$ comprises two anthropogenic elements $\mathrm{Cd}$, and $\mathrm{Pb}$ as well as humic acids - HA (possibly organic complexes with heavy metals), and Chl $a$ (indicative of primary production intensity). These are closely associated with concentrations of Mn (indicator of red-ox potential shifts) and branched fatty acids BRANCHED (indicator of microbial activity). In cluster $d$ fatty acids, excluding the saturated ones, are grouped. These are associated with calcium carbonate concentration, indicating contribution of mussels abundant in the Pomeranian Bay: Mytilus edulis, Mya arenaria, and Macoma balthica (Warzocha, 1994) to the pool of fresh organic matter (unsaturated fatty acids are a labile fraction of organic matter - Pazdro et al., 2001). It is quite likely that the mussels contribute to the enrichment of FLSM with $\mathrm{Cd}$ and $\mathrm{Pb}$, since Mytilus edulis is known to accumulate Cd, while Mya arenaria and Macoma balthica preferentially accumulate $\mathrm{Pb}$ (Szefer, 1987).

Cluster $e$ indicates close relation between distribution of stable isotopes in organic matter, and concentration of chromium. Distribution of stable isotopes is closely related to the provenience of organic matter. It is also the property characterized by the smallest standard deviations of average concentrations at subsequent stations, and exhibiting the well developed trend (95\% of land derived organic matter at the OT station; $5 \%$ of land derived organic matter at the AB station). It may be assumed, therefore, that chromium in FLSM is supplied to the system with the Odra River run-off, and distributed similarly to land derived organic matter (steep gradient of land derived components off-shore). It is interesting

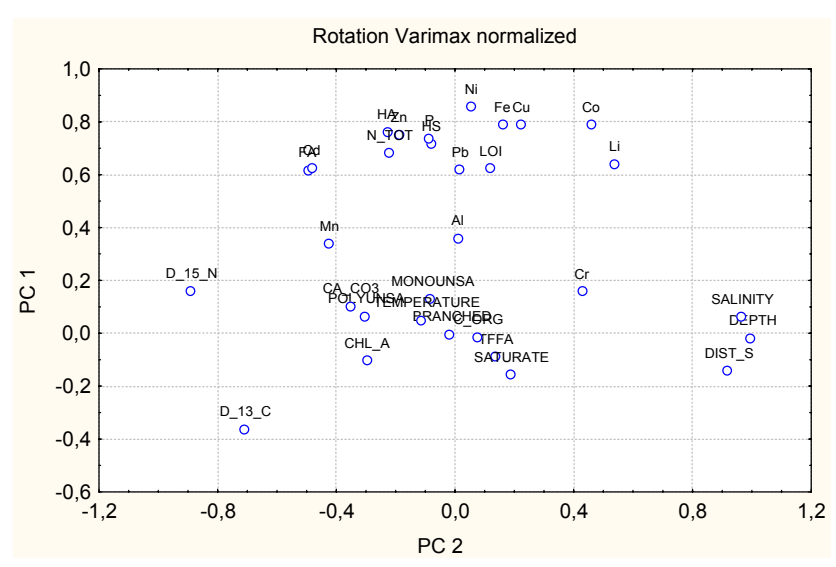

Fig. 10. Scatterplot of the object samples properties loadings in space spanned by axis PC1 and PC2 of the analysed data set.

to see that saturated fatty acids, are also included in the $e$ cluster. The feature strongly supports conclusions of Pazdro et al. (2001) who pointed at long chain saturated fatty acids, a stable fraction of organic matter, as closely related to the land derived organic matter.

\subsection{Principal components analysis (PCA)}

In Table 4 results of PCA are presented. The first five principal components (PC) are responsible for some $74 \%$ of the data scatter. The PC6 eigenvalue indicates contribution differing little from contributions of each of the thirty variables included in the data set. Basing on PCs eingenvalues the number of evaluated PCs was limited to the first five. Loadings of the PCs, subjected to further analysis, are presented in Table 5. In Fig. 10 distribution of PC1 and PC2 loadings is presented in the scatterplot of individual variables in space spanned by axis PC1 and PC2.

A number of FLSM properties exhibit PC1 loadings exceeding 0.6. These include $\mathrm{Cu}, \mathrm{Co}, \mathrm{Ni}, \mathrm{Fe}, \mathrm{LOI}, \mathrm{Li}, \mathrm{P}, \mathrm{N}$ (components of the $a$ cluster - Fig. 9), $\mathrm{Zn}$, and $\mathrm{Pb}$. The 
Table 4. Results of PCA.

\begin{tabular}{ccccc}
\hline \multirow{2}{*}{ Principal Component } & \multicolumn{3}{c}{ Characteristics } \\
\cline { 2 - 5 } & Eigenvalue & Explained variability(\%) & Cumulative eigenvalue & Cum.explained variability $(\%)$ \\
\hline 1 & 8.53 & 25.11 & 8.53 & 25.11 \\
2 & 7.22 & 21.23 & 15.76 & 46.35 \\
3 & 3.67 & 10.85 & 19.45 & 57.21 \\
4 & 2.88 & 8.49 & 22.33 & 65.70 \\
5 & 2.73 & 8.05 & 25.07 & 73.75 \\
6 & 1.67 & 4.92 & 26.75 & 78.68 \\
7 & 1.37 & 4.05 & 28.13 & 82.73 \\
\hline
\end{tabular}

Table 5. The first five PCs loadings.

\begin{tabular}{|c|c|c|c|c|c|}
\hline \multirow{2}{*}{ Properties } & \multicolumn{5}{|c|}{ PC loadings (Varimax rotation) } \\
\hline & $\mathrm{PC}_{-} 1$ & PC_2 & PC_3 & PC_4 & PC_5 \\
\hline LOI & 0.615827 & -0.131215 & 0.135703 & -0.116643 & -0.158778 \\
\hline $\mathrm{HA}_{-} \%_{-}$ & 0.764951 & 0.244689 & 0.031128 & 0.016921 & 0.063215 \\
\hline FA_\% & 0.622782 & 0.521088 & 0.096235 & -0.122844 & 0.048274 \\
\hline HS_\% & 0.717535 & 0.091280 & -0.017029 & 0.200468 & -0.341112 \\
\hline TFAF & -0.103623 & -0.148583 & 0.804567 & 0.298030 & 0.152843 \\
\hline SATURATE & -0.151261 & -0.197577 & -0.894538 & 0.149026 & -0.069372 \\
\hline MONOUNSA & 0.134285 & 0.103319 & 0.802867 & -0.324078 & 0.060624 \\
\hline POLYUNSA & 0.056482 & 0.312121 & 0.825113 & 0.093179 & 0.133130 \\
\hline BRANCHED & 0.023038 & 0.065904 & 0.227170 & -0.770905 & 0.094131 \\
\hline PB & 0.622738 & -0.018872 & -0.103822 & -0.339346 & 0.230029 \\
\hline $\mathrm{CU}$ & 0.806217 & -0.195065 & -0.110383 & -0.374885 & 0.184319 \\
\hline $\mathrm{CD}$ & 0.610996 & 0.475611 & 0.341783 & 0.007825 & 0.148894 \\
\hline $\mathrm{FE}$ & 0.795886 & -0.147878 & 0.073624 & -0.285510 & -0.050702 \\
\hline $\mathrm{CR}$ & 0.169184 & -0.408616 & 0.061850 & 0.203638 & 0.626316 \\
\hline $\mathrm{MN}$ & 0.358417 & 0.465929 & -0.277963 & -0.379490 & -0.297228 \\
\hline $\mathrm{CO}$ & 0.798616 & -0.444187 & -0.174920 & -0.054096 & -0.024167 \\
\hline NI & 0.854760 & -0.051373 & 0.072531 & 0.194649 & 0.105215 \\
\hline $\mathrm{ZN}$ & 0.744949 & 0.187217 & 0.080519 & 0.118211 & -0.202666 \\
\hline $\mathrm{AL}$ & 0.331586 & -0.051579 & 0.516195 & 0.403984 & -0.258158 \\
\hline N_TOT \% & 0.674489 & 0.228624 & 0.342183 & 0.298404 & 0.214571 \\
\hline CA_CO3 \% & 0.081751 & 0.333692 & 0.252231 & 0.718889 & 0.159130 \\
\hline$\delta \_15 \_\mathrm{N}$ & 0.151160 & 0.893782 & 0.164908 & 0.043205 & 0.215380 \\
\hline S_13_C & -0.372765 & 0.705305 & 0.265600 & 0.145884 & -0.069663 \\
\hline LI_PPM & 0.642370 & -0.535120 & -0.078994 & 0.360288 & 0.150337 \\
\hline P_PPM & 0.735087 & 0.099368 & 0.251127 & 0.273612 & 0.131260 \\
\hline C_ORG & 0.689340 & 0.229371 & 0.042478 & -0.224912 & 0.138206 \\
\hline Depth & -0.005356 & -0.989345 & -0.055603 & -0.043507 & -0.006959 \\
\hline Distance & -0.134794 & -0.924796 & 0.005893 & -0.034832 & -0.136303 \\
\hline Salinity & 0.076838 & -0.953152 & -0.090243 & -0.043946 & 0.071806 \\
\hline CHL_a & -0.113655 & 0.286276 & 0.260015 & 0.128807 & 0.736589 \\
\hline Eigenvalue & 7.774360 & 6.036083 & 3.816995 & 2.534828 & 2.349314 \\
\hline Expl.variance & 0.2511 & 0.2123 & 0.1085 & 0.0849 & 0.0805 \\
\hline
\end{tabular}

pattern indicates that PC1 meaning could be attributed to contribution of lithogenic (land) derived material in FLSM. The eigenvalue of 8.53 corresponds to $25.1 \%$ of total vari- ability in the data set. The PC2 (eigenvalue 7.22, variance $21.2 \%)$ is characterized by large loadings of stable isotopes $\left(\delta^{15} \mathrm{~N}, \delta^{13} \mathrm{C}\right)$, salinity, water depth, and distance from the 
Table 6. Summary of PCA.

\begin{tabular}{llll}
\hline \multirow{2}{*}{ PC } & \multicolumn{2}{c}{ Explained } & Assigned meaning \\
\cline { 2 - 4 } & Variability $\%$ & Cum. Variab. $\%$ & $\begin{array}{l}\text { Distribution of heavy metals and humic substances. Contribution of lithogenic } \\
\text { and land derived material. }\end{array}$ \\
\hline 1. & 25.1 & 25.1 & $\begin{array}{l}\text { Distance from the shore, contribution of autochthonous material. Influence } \\
\text { of time dependent processes (abrasion, fine sediment fraction, autohtonous } \\
\text { organic matter, atmospheric deposition). }\end{array}$ \\
\hline 3. & 21.2 & 46.3 & Distribution of straight chain fatty acids. Contribution offresh organic matter. \\
\hline 4. & 8.5 & 57.2 & Distribution of branched fatty acids. Microbial activity. \\
\hline 5. & 8.1 & 65.7 & Chl.a, Temperature. Seasonality of properties.
\end{tabular}

shore (the Odra river mouth). Salinity and water depth increase with increasing distance from the river mouth, while contribution of land derived organic matter decreases sharply from $95 \%$ at the nearshore OT station, to $5 \%$ at the offshore AB station (Emeis et al., 2002). Therefore the distance from the Odra River mouth can be assigned as actual meaning of PC2. It is worth stressing that distance from the shore, in this instance, describes collectively a number of time dependent factors decisive for the FLSM properties. These will include contribution of autochthonous organic matter (Voss and Stock, 1997; Emeis et al., 2002), time factor important for the load of fine sediment fraction contributing to FLSM (Pempkowiak et al., 2002), atmospheric input (Löffler et al., 2000; Witt et al., 2001), and both autohtonous organic matter production and biochemical degradation (Pazdro et al., 2001).

This assignment is supported by the PC2 loadings exceeding 0.9 for a set of variables closely attributed to the distance from the shore. It is also strongly supported by distribution of sample scores presented in Fig. 11, in space spanned by axis PC1 and PC2. Samples collected at subsequent stations are separated into clusters according to PC2 scores. It is interesting to notice the strong separation of the Arkona Becken samples, and much weaker separation of samples collected at the other stations. This is in agreement with cluster analyses presented in Fig. 8. No seasonal pattern can be assigned to either PC1 or PC2. Some attention is to be paid to the fact that PC1 scores of samples collected at different stations do not separate them. This originates from, and supports, the meaning assigned to PC1. Material of land origin is, after all, a major component of FLSM collected at all stations (Löffler et al., 2000; Leipe et al., 2000). One exception is organic matter as indicated by stable isotopes $\left(\delta^{15} \mathrm{~N}, \delta^{13} \mathrm{C}\right)$, and chromium, most likely, due to the steep gradient, and lack of land associated contents at the offshore stations.

Distribution of straight chain fatty acids sets PC3 (Table 5). Since saturated fatty acids (large positive PC3 load-

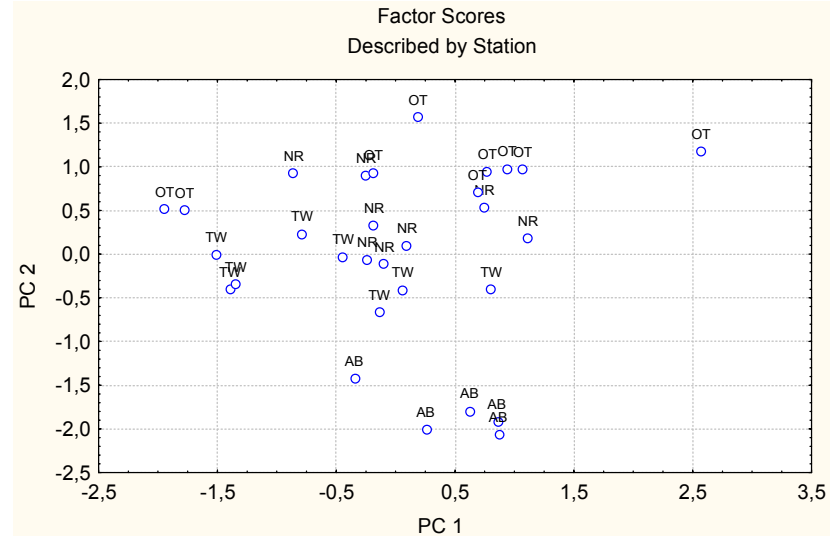

Fig. 11. Scatterplot of the object samples scores in space spanned by axis PC1 and PC2 of the analysed data set.

ing) are relatively resistant to biodegradation, while monoand poly-unsaturated ones (large negative PC3 loadings) are considered to be labile (Pazdro et al., 2001; Canuel and Martens, 1996), the PC3 differentiate between fresh and old organic matter. Distribution of branched fatty acids sets PC4. This fraction of fatty acids originate from bacterial activity (Brown et al., 1996; Pazdro et al., 2001). Therefore, it can be safely assumed that $\mathrm{PC} 4$ represents the influence of bacterial activity on FLSM properties. Both $\mathrm{Al}$ and $\mathrm{CaCO}_{3}$ concentrations are characterized by substantial PC4 loadings values. Both are opposite to branched fatty acids loading. Both water temperature and Chl $a$ show large PC5 loading values. Water temperature is closely related to season as is Chl $a$. Therefore, conclusions drawn from the time related pattern of properties discussed earlier and presented in Fig. 8 and Table 3, combined with the meaning of PC5 indicate seasonality of the properties. In Table 6 summary of PC eigenvalues and actual meaning assigned to subsequent principal components is given. 


\section{Conclusions}

FLSM samples were collected from four stations situated along a main route of currents leading from the mouth of the Odra River to the depositional area at the Arkona Deep in the period December 1996-December 1998.

Twenty six properties of the samples were analysed. These included concentrations of heavy metals (Ni, $\mathrm{Co}, \mathrm{Fe}, \mathrm{Mn}, \mathrm{Zn}$, $\mathrm{Cd}, \mathrm{Cu}, \mathrm{Pb}, \mathrm{Cr}, \mathrm{Al}$ ), organic matter (Loss on ign., $\mathrm{C}_{\text {org }}, \mathrm{N}_{\text {tot }}$, $\left.\mathrm{P}_{\text {tot }}, \delta^{13} \mathrm{C}, \delta^{15} \mathrm{~N}\right)$, organic matter fractions differing with resistance to degradation (humic substances, fatty acids), and shell debris $\left(\mathrm{CaCO}_{3}\right)$. The so obtained data set, amended with environmental characteristics of the sampling sites, was then subjected to statistical analyses. The FLSM spatial changes caused by the land derived material dilution with the autochthonous one were documented. Seasonal changes, although less visible, were also noticed. Applying multivariate statistical analysis (both PCA and CA) led to dimensionality reduction in the data set. Contribution of lithogenic material (PC1 - 25\%), influence of time dependent processes including contributions of autochthonous organic matter, atmospheric input, fine fractions of sediments, biochemical degradation (PC2 - 21\%), contribution of fresh organic matter (PC3 - 13\%), bacterial activity (PC4 - 8\%), and seasonality (PC5 - 8\%) were recognized as main factors controlling properties of FLSM in the investigated system. Samples clustering indicated both Arkona Deep and the Odra River mouth as end members of the FLSM in the system. The FLSM properties changed substantially on passage from the high energy shallow environment to the depositional area. On several instances the passage time was evaluated to be in the range from 4 to 9 month.

Acknowledgements. This study was financially supported by the Institute of Oceanology, Sopot statutory activity, grant no II.2/2003.

Edited by: A. Reeves

\section{References}

Alldredge, A. and Gotschalk, S.: The relative contribution of marine snow of different origins to biological processes in coastal water, Cont. Shelf. Res., 10, 41-58, 1990.

Bale, A. and Morris, A.: Organic carbon in suspended particulate material in the North Sea: Effect of mixing resuspended and background particles, Cont. Shelf Res., 18, 1333-1345, 1998.

Belzunce, H., Solaun, O., Franco, J., Valemia, V., and Borja, A.: Accumulation of organic matter, heavy metals, and organic compounds in surface sediments along the Nervion Estuary (Northern Spain), Mar. Poll. Bul., 42, 1407-1411, 2001.

Bianchi, T., Mitra, S., and McKee, B.: Sources of terrestriallyderived organic carbon in lower Mississippi River and Louisiane shelf sediments, Implications for differential sedimentation and transport at the coastal margin, Mar. Chem., 77, 211-223, 2002.

Bordowsky, O.: Accumulation and transformation of organic substances in marine sediments, Mar. Geol., 3, 3-114, 1965.
Borg, H. and Jonsson, P.: Large-scale metal distribution in Baltic Sea sediments, Mar. Poll. Bul., 32, 8-21, 1996.

Brown, Ch. E.: Applied multivariate statistic in geohydrology and related sciences, Springer, Berlin 1998, 248 pp., 1998.

Brown, M. R., Barrett, S. M., Volkman, J. K., Nearhos, S. P., Nell, J. A., and Allan, G. L.: Biochemical composition of yeasts and bacteria evaluated as food for bivalve aquaculture, Aquaculture, 143, 341-360, 1996.

Canuel, E. and Martens, Ch.: Reactivity of recently deposited organic matter: degradation of lipid compounds near the sedimentwater interface, Geochim. Cosmochim. Acta, 60, 1793-1806, 1996.

Christiansen, C., Edelvang, K., Emeis, K., Graf, G., Jähmlich, S., Kozuch, J., Laima, M., Leipe, T., Löffler, A., Lund-Hansen, L. C., Miltner, A., Pazdro, K., Pempkowiak, J., Shimmield, G., Shimmield, T., Smith, J., Voss, M., and Witt, G.: Material transport from the nearshore to the basinal environment in the southern Baltic Sea I. Processes and mass estimates, J. Mar. Sys., 35 133-150, 2002.

De Lazzari, A., Pampazzo, G., and Pavoni, B.: Geochemistry of sediments in the Northern and Central Adriatic Sea, Estuar. Coastal Shelf Sci., 59, 429-440, 2004.

Dehairs, F., Baeyens, W., and van Gansbeke, D.: Tight coupling between enrichment of iron and manganese redox processes: evidence for seasonal variability, Estuar. Coast. Shelf. Sci., 29, 457471, 1989.

Duursma, E. and Carroll, J. L.: Environmental compartments, Springer, Berlin 1996, 277 pp., 1996.

Emeis, K.-C., Christiansen, C., Edelvang, K., Jähmlich, S., Kozuch, J., Laima, M., Leipe, T., Löffler, A., Lund-Hansen, L., Miltner, A., Pazdro, K., Pempkowiak, J., Shimmield, G., Shimmield, T., Smith, J., Voss, H., Witt, G.: Material transport from the nearshore to the basinal environment in the southern Baltic Sea. II: Origin and properties of material, J. Mar. Sys., 35, 151-168, 2002.

Gerino, M.: The effect of bioturbation on particle redistribution in Mediterranean coastal sediment, Hydrobiologia, 207, 251-258, 1990.

Gustafsson, O., Buesseler, K., Geyer, W., Moran, S., and Gschwend, P.: An assessment of the relative importance of horizontal and vertical transport of particle-reactive chemicals in the coastal ocean, Cont. Shelf Res., 18, 805-829, 1998.

Heiser, U., Neumann, T., Scholten, J., and Stüben, D.: Recycling of manganese from anoxic sediments in stagnant basins by seawater inflow: a study of surface sediments from the Gotland Basin, Baltic Sea. Mar. Geol., 177, 151-166, 2001.

Hinrichs, J., Dellwig, O., and Brumsack, H.-J.: Lead in sediments and suspended particulate matter of the German Bight: natural versus anthropogenic origin, Appl. Geochem., 17, 621-632, 2002.

Jago, C. and Jones, S.: Observation and modelling of the dynamics of benthic fluff resuspended from a sandy bed in the southern North Sea, Cont. Shelf Res., 18, 1255-1282, 1998.

Jones, S., Jago, C., Bale, A., Chapman, D., Howland, R., and Jackson, J.: Aggregation and resuspension of suspended particulate matter at a seasonally stratified site in the southern North Sea: Physical and biological controls, Cont. Shelf Res., 18, 12831309, 1998. 
Krumgalz, L.: "Fingerpprints" approach to the identification of anthropogenic trace metal sources in nearshore and estuarine environments, Estuaries, 16, 488-495, 1993.

Laima, M., Lund-Hansen, L., Pazdro, K., Christiansen, C., and Emeis, K.-C.: Near bottom fluxes and composition of suspended matter in the Pomeranian Bay, Oceanologia, 41, 335-353, 1999.

Leipe, T., Loeffler, A., Emeis, K.-C., Jaehmlich, S., Bahlo, R., and Siervogel, K.: Vertical patterns of suspended matter characteristics along a coastal-basin transect in the Western Baltic Sea, Estuar. Coastal Shelf Sci., 51, 789-804, 2000.

Liu, W., Li, X., Shen, Z., Wang, D., Wai, O., and Li, Y.: Multivariate statistical study of heavy metals enrichment in sediments of the Pearl River Estuary, Envir. Poll., 121, 377-388, 2003.

Löffler, A., Leipe, T., and Emeis, K.-C.: The fluffy layer in the Pomeranian Bight (western Baltic Sea): geochemistry, mineralogy and environmental aspect, Meyniana, 52, 85-100, 2000.

Lund-Hansen, L., Christiansen, C., Jensen, O., and Laima, M.: The LABREX chamber for studying the critical shear stress for finegrained sediments, Danish J. Geogr., 99, 1-7, 1999.

Lund-Hansen, L., Valeur, J., Pejrup, H., and Jensen, A.: Sediment fluxes, resuspension and accumulation rates in two wind-exposed coastal sites and in a sheltered bay, Estuar. Coastal Shelf Sci., 44, 521-531, 1997.

Manly, B.: Multivariate statistical methods, A primer. Chapman and Hall, London 1990, 157 pp., 1990.

Martino, M., Turner, A., Niemmo, M., and Millward, G.: Resuspension, reactivity and recycling of trace metals in the Mersey Estuary, Mar. Chem., 77, 171-186, 2002.

Mayer, L.: Extent of coverage of mineral surfaces by organic matter in marine sediments, Geochim. Cosmochim. Acta, 63, 207-215, 1999.

Mayer-Reil, L.: Microbial life in sedimentary biofilms - the challenge to microbial ecologists, Mar. Eco. Prog. Sr., 112, 303-311, 1994.

Meglen, R.: Examining large databases: a chemometric approach using principle component analysis, Mar. Chem., 39, 217-238, 1992.

Miltner, A. and Emeis, K.: Terrestrial organic matter in surface sediments of the Baltic Sea, Northwest Europe, as determined by $\mathrm{CuO}$ oxidation, Geochim. Cosmochim. Acta, 65, 1285-1299, 2001

Pazdro, K. and Falkowski, L.: Determination of free fatty acids in marine environment by means of high performance liquid chromatography (applying their uv absorbing and fluorescence esters), Oceanol. Studies, 67, 15-26, 1994.

Pazdro, K., Staniszewski, A., Beldowski, J., Emeis, K., Leipe, T., and Pempkowiak, J.: Variations in organic matter bound in fluffy layer suspended matter from the Pomeranian Bay, Oceanologia, 43, 405-420, 2001.

Pempkowiak, J.: Rozmieszczenie, pochodzenie i wlaściwosci kwasów humusowych w Morzu Baltyckim, Ossolineum, Wroclaw 1989, 146 pp., 1989.

Pempkowiak, J.: Enrichment factors of heavy metals in the southern Baltic surface sediments dated with ${ }^{210} \mathrm{~Pb}$ and ${ }^{137} \mathrm{Cs}$, Environ. Int., 17, 421-428, 1991.

Pempkowiak, J., Beldowski, J., Pazdro, K., Staniszewski, A., Leipe, T., and Emeis, K.-C.: The contribution of the fine sediment fraction to the fluffy layer suspended matter, Oceanologia, 44(4), 513-527, 2002
Pempkowiak, J., Chiffoleau, J.-F., and Staniszewski, A.: The vertical and horizontal distribution of selected trace metals in the Baltic Sea off Poland, Estuar. Coast. Shelf Sci., 51, 115-125, 2000.

Pempkowiak, J. and Szponar, Z.: The complexing properties of humic substances isolated from Baltic sediments and their molecular weight fractions, Oceanologia, 34, 39-47, 1995.

Persson, T. and Wedborg, M.: Multivariate evaluation of the fluorescence of aquatic organic matter, Anal. Chim. Acta, 434, 1791992, 2001.

Podani, J.: Introduction to the exploration of multivariate biological data, Backhuyes Pub., Leiden 2000, 407 pp., 2000.

Pohl, C., Hennings, U., Petersohn, I., and Siegel, H.: Trace metal budget, transport, modification and sink in the transition area between the Oder and Peene rivers and the Southern Pomeranian Bight, Mar. Poll. Bull., 36, 598-616, 1998.

Reimann, C., Filllzmoser, P., and Garrett, R.: Factor analyses applied to regional geochemical data: problems and possibilities, Appl. Geochem., 17, 185-206, 2002.

Ruessink, B., van Enckevort, I., and Kuriyama, Y.: Non-linear principal component analysis of nearshore bathymetry, Mar. Geol., $203,185-197,2004$.

Shine, J., Ika, R., and Ford, T.: Multivariate statistical-examination of spatial and temporal patterns of heavy metal contamination in New Bedford Harbor marine sediments, Envir. Sci. Tech., 29, 1781-1788, 1995.

Siegel, H., Gerth, M., and Mutzke, A.: Dynamics of the Oder river plume in the Southern Baltic Sea: satellite data and numerical modelling, Cont. Shelf Res., 19, 1143-1159, 1999.

Smoliñski, A., Walczak, B., and Einax, J.: Exploratory analysis of data sets with missing elements and outliers, Chemosphere, 49, 233-245, 2002.

Staniszewski, A., Pazdro, K., Beldowski, J., Leipe, T., Emeis, K., and Pempkowiak, J.: Temporal and spatial changes of cadmium in the near-bottom suspended matter of the Pomeranian Bay Arkona Deep system, Oceanologia, 42, 483-491, 2001.

Sun, M. Y., Wakeham, S. G., and Lee, C.: Rates and mechanisms of fatty acids degradation in oxic and anoxic coastal marine sediments of Long Island Sound, New York, USA, Geochim. Cosmochim. Acta, 61, 341-355, 1997.

Szefer, P.: Interelemental relationship in organisms and bottom sediments of the Southern Baltic, Sci. Tot. Environ., 95, 119-130, 1987.

Szefer, P., Glasby, G., Pempkowiak, J., and Kaliszan, R.: Extraction studies of heavy-metal pollutants in surficial sediments from the southern Baltic Sea off Poland, Chem. Geol., 120, 111-126, 1995.

Thomsen, L. and Ritzrau, W.: Aggregate studies in the benthic boundary layer at a continental margin, J. Sea Res., 36, 143-146, 1996.

Voss, M. and Stock, U.: Stable nitrogen and carbon isotopes as indicator of eutrophication of the Odra river (Baltic Sea), Mar Chem., 59, 35-49, 1997.

Wakeham, S. G., Hedges, J. L., Hernes, P., and Peterson, M.: Molecular indicators of diagenetic status in marine matter, Geochim. Cosmochim. Acta, 24, 5363-5369, 1997.

Warzocha, J.: Spatial distribution of macrofauna in the Southern Baltic, Bull. Sea Fish. Inst., 1(131), 61-66, 1994. 
Wheatcroft, R.: A mechanistic view of the particulate brodiffusion coefficient: step lengths, rest period, and transport direction, J. Mar. Res., 48, 177-207, 1992.

Widrowski, H. and Pempkowiak, J.: The history of surface sediments in the Southern Baltic, Proc. 15th Conf. Baltic Oceanogr., Mar. Pollut. Lab., Copenhagen, 656-671, 1986.
Witt, G., Leipe, T., and Emeis, K.: Using fluffy layer material to study the fate of particle-bound organic pollutants in the southern Baltic Sea, Envir. Sci. Tech., 35, 1563-1573, 2001.

Wiwant, C., Inman, D., and Nordstrom, C.: Description of seasonal beach changes using empirical eigenfunction analysis, J. Geophys. Res., 80, 1979-1986, 1975. 